\title{
Nurturance Effects of the New Cognitive Style-Based Learning Strategy in Science Learning
}

${ }^{1 s t}$ Arif Sholahuddin

Faculty of Teacher Training and Education, Lambung Mangkurat University Banjarmasin, Indonesia arif.science.edu@unlam.ac.id
${ }^{2 n d}$ Leny Yuanita

Post Graduate Program, Surabaya State University, Indonesia lennyyuanita@unesa.ac.id
${ }^{3 r d}$ Z. A. Imam Supardi

Post Graduate Program, Surabaya State University, Indonesia zainularifin@unesa.ac.id

\begin{abstract}
This research is the field trial stage of research and development of the new cognitive-based learning strategy called @UnESa-GAIn. Basically, this learning strategy is designed for students in concrete cognitive development to improve mainly instructional effects of conceptual understanding, problem-solving ability, and process skills. This study aims to investigate the nurturance effects of the learning strategy as social skills and character traits. The observed social skills consist of communicating effectively, listening to others, respecting the opinions of others, working together, and contributing ideas, while the observed character traits include meticulous, honest, and responsible. This study was conducted in two elementary schools in different location namely SDN Pasar Lama 1 and SDN Pasar Lama 3 Banjarmasin Indonesia involving 72 students.By implementing one shoot case study along ten times classroom meetings, it is found that the nurturance effects of the learning strategy both the social skills and character traits have reached a good category. They tend to increase along the classroom meetings. The social skills and character traits that still need to be improved especially in SDN Pasar Lama 1 are listening to the others and being honest respectively. Students with field independence (FI) cognitive styles tend to achieve better nurturance effects than field dependence (FD) cognitive styles. This finding is an anomaly because generally, FD students tend to prefer social activities and have better social skills than FI students. It is suggested that to accomplish the good social skills, the learning strategy has to be implemented in a collaborative approach. The new strategy gives a wide contribution toin-depth learning early to achieve instructional as well as nurturance effects of learning by considering individual differences.
\end{abstract}

Keywords- learning strategy, cognitive style, field independence, field dependence, nurturance effects, social skills, character traits

\section{INTRODUCTION}

The 2013 curriculum emphasizes the cultivation of attitudes or values to students as the first priority before mastery of knowledge and skills. This cultivation of attitudes or values is no longer the sole responsibility of religion education, civic education, and counseling guidance, but involving all fields of study (Ministry of Education and Culture, 2012). Therefore, teachers must be able to integrate the values or characters into the subjects taught. Moreover, through Presidential Regulation no. 87 of 2017 the application of character building is strengthened through formal, informal, and nonformal education in the context of applying Pancasila values in character building. The intended developed characters include religious, honest, tolerant, discipline, hard work, creative, independent, democratic, curious, nationalism, love of the homeland, appreciative of achievement, communicative, love of peace, love of reading, environmental care, social care, and responsible.

The integration of character values through the field of study is an effective way because teachers are more knowledgeable about what characters can be inculcated through a series of classroom activities. The implementation of character building in learning requires the ability of teachers to identify the characteristics of subject matter and determine what characters that can be developed through the learning. Furthermore, teachers should make learning plans that include choosing appropriate strategies to instill certain characters.

In Indonesia itself, the teachers have done the integration of character building to the field of study although it was not optimal yet. This integrating of character in the field of study has various forms such as the application of learning strategies, use of media, evaluation tools, and development of learning material that are potential to teach it. These teachers were able to identify the character of appropriate values for integration with the subject matter. However, they appear to be limited in skills and 
hesitant in applying the correct methods during the teaching-learning processes (Hadi, 2015). In line with Hadi, teachers were still difficult to integrate spiritual attitude and social attitude in planning and conducting of learning (Sutarto, Jaedun, \& Nuryadin, 2017). The performance of science teachers to the integration of science learning with character building on the aspects of developing lesson plans, learning aspects, and assessment aspects were categorized into the good category. Even so, the plan has not been fully implemented in science learning classroom. Character building is also applied by teachers in developing tests to measure students' concept of science understanding (Isdaryanti, Rachman, Sukestiyarno, Florentinus, \& Widodo, 2018). Integrating character into learning has proven effective in strengthening students' scientific attitudes (Sardjijoa \& Hapzi, 2017) and instilling care and tolerant attitudes (Ibrahim \& Abadi, 2018) as well as values of teamwork and responsibility (Eliasa, 2014).

One of the factors determined the successes of integrated character education is the role of learning strategies that facilitate the inculcation of character values through the learning process in the classroom. The 2013 Curriculum has recommended the inquirybased learning strategies to train the scientific skills (observing, questioning, experimenting, associating, and communicating) as well as instilling characters. These strategies include inquiry-based learning, problem-based learning, and project-based learning. Chan, Sidhu, Suthagar, Lee, and Yap (2016) argue that inquiry-based learning is an integral part of the active learning approach which encouragesstudents to think and involve in the investigation process. The active learning directly resulted in increasing of conceptual understanding. However, these strategies had general property and involving a level of formal thinking development of children who do not reach elementary school level yet. In addition, the existing learning strategies are not designed to facilitate students' learning styles. In many studies, it can be seen that conceptual understanding that was achieved through problem-solving-based strategies was inconsistent, even no difference to traditional expository strategies (Sholahuddin, Yuanita \& Kardi, 2013).

As a result, in responding to the above issue, we have developed a new cognitive style-based learning strategy called @UneSa-GAIn. The @)UneSa-GAIn is an acronym of Attention (@ = at), Understanding Problem (Un), Exploration (E), Sharing (Sa), Game (G), Assessment (A) and Individual Task (In). It has passed the chain of experts validation and trials (Sholahuddin, Yuanita, Kardi, 2014). It is developed to accommodate concrete cognitive development as well as cognitive style. The user targets of this strategy are the students with concrete cognitive development (age 6-11 years), so their scientific ability can be developed early through the science learning. At this age, students are able to think logically as long as the thinking is applied to known, concrete and applicative examples (Santrock, 2007; Slavin, 2009).

Another important characteristic of this strategy is that it accommodates students' differences in information processing which was known as cognitive style (Altun \& Cakan, 2006; Ardhana, 2008; Armstrong et al., 2012; Cano, 1993; Davis, 2006). Students of FD cognitive style find it difficult to separate items of an object from their original form, ends to perceive objects globally, and usually finds more difficulty in solving problems. Meanwhile, students with FI cognitive styles are able to understand abstract elements from their context, tend to be more analytical and use problem-solving approaches in an analytical way, and are good in seeing specific differences to get simple items on complex objects. In other words, accommodations of both individual characteristics are expected to facilitate them to learn optimally.

Another advantage of the @UneSa-GAIn Cognitive Style-Based Learning Strategy is the existence of a rehearsal game stage for providing a relaxed atmosphere in accordance with the characteristics of children, as well repeating the related concepts to support the mastery and retention of knowledge that has been studied. This rehearsal game is appropriate to the systems that apply standardized exams to measure graduate competencies, such as national exams in Indonesia.

The@UneSa-GAIn Cognitive Style-Based Learning Strategy is designed to achieve instructional effects in the form of conceptual understanding, problem-solving skills, and science process skills. This paper discusses specifically the other important side of the learning strategy, namely the nurturance effects, the effects of learning that is not designed in the implementation plan of learning. In the 2013 curriculum, the achievement of basic competence (BC) is the effects of learning: BC-1 (attitude of divinity) and $\mathrm{BC}-2$ (social attitude) are the nurturance effects, while CB-3 (knowledge) and CB-4 (skill) are the instructional effects of learning (Rule of Indonesian Ministry of Education and Culture No. 81A 2013). In addition, the attitude (social skills and character traits) as nurturance effects is considered in this paper becauseit does not mean that the attitude cannot be inculcated by design through instruction.

\section{METHOD}

This study applied the research and development design of Dick, Carey \& Carey (2015) on the step of field trial evaluation. This study reports specifically on nurturance effects due to the application of the @UneSa-GAIn Cognitive Style-Based Learning Strategy in the scienceclassroom. The nurturance effects includesocial skills (effective communication, listening to others, respecting the opinions of others, helping each other or collaborating, and contributing) and character traits (meticulous, honest, and responsible) (Fogarty, 2009 Rule of Indonesian 
Ministry of Education and Culture, 2016). This field trial evaluation was conducted at two different schools representing advanced and developed of national state elementary schools in Banjarmasin according to the School Accreditation Council of South Kalimantan, Indonesia. The representative schools were SDN Pasar Lama 1 and SDN Pasar Lama 3 Banjarmasin with a number of 72 students. Teachers who have trained in implementing the learning strategy taught at each school for ten meetingsin the science classroom. This strategy was carried out in science learning on the topic of insulators and substance change.

There were six lesson plans (or RPP) implemented during the ten meetings and the nurturance effects were observed in the first RPP, the third RPP, and the sixth RPP. Assessment of the nurturance effects in each school was conducted by two observers from professional teachers who had been trained previously. The observations were made using an observation sheet and assessment rubric that had been validated by five experts and was declared valid based on the Cohen criteria (2010). The developed assessment tools usedLikert model with the score ranging from $1-4 ; 1=$ poor, $2=$ moderate, $3=$ good, 4 $=$ excellence. Further, data were analyzed qualitatively to see the development of social skills and behavioural traits as well as the developmental trend of social skills and behavior traits of students who have different cognitive styles.

\section{FINDINGS}

Fig. 1 and Fig. 2 show the students' social skills of SDN Pasar Lama 1 and SDN Pasar Lama 3 Banjarmasin respectively. The social skills observed consist of (1) communicating effectively, (2) listening to others, (3) respecting the other's opinions, (4) helping each other or work together, and (5) contributing ideas.

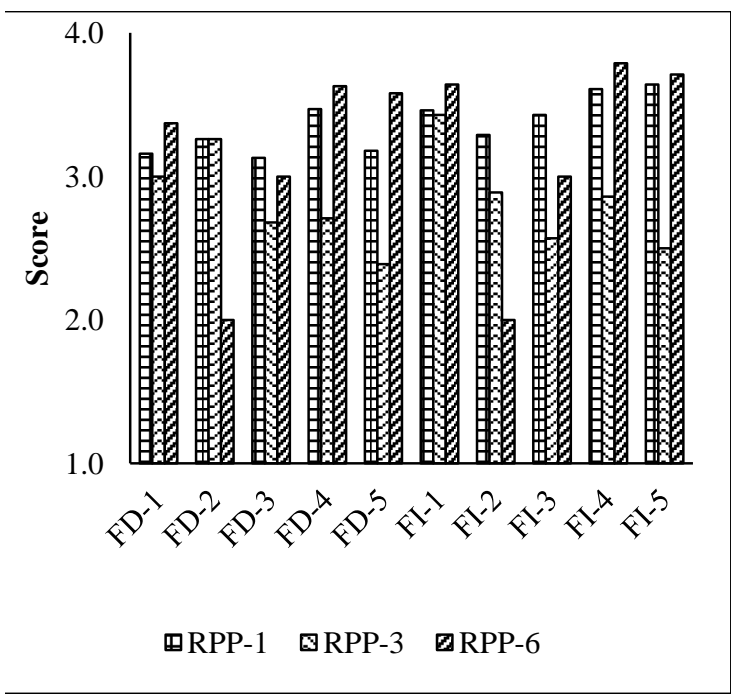

Figure 1.Students' social skills of SDN

Pasar Lama 1 Banjarmasin; FD-1 = Field Dependence for indicator-1, FI-1 = Field Independence for indicator-1.

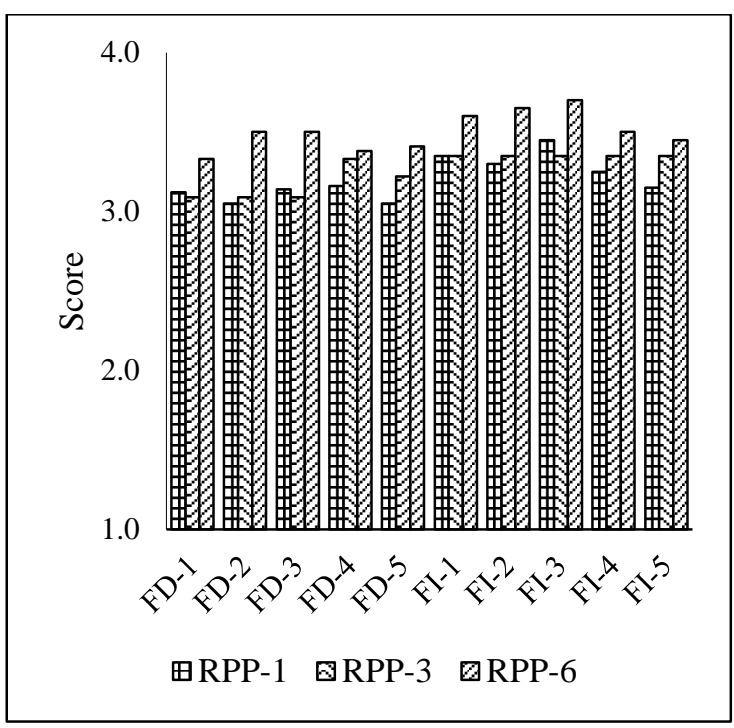

Figure 2.Students' social skills of SDN

Pasar Lama 3 Banjarmasin; FD-1 = Field Dependence for indicator-1, FI-1 = Field Independence for indicator-1.

Fig. 3 and Fig. 4 show the students' character traits of SDN Pasar Lama 1 and students of SDN Pasar Lama 3 Banjarmasin respectively. The character traits observed include: (1) conscientiously: performing step-by-step activities in accordance with procedures, describing detailed observation data, and writing data or information without errors in both sentences and concepts (2) honest: writing or submitting data or facts as is, writing down sources if quoting from others, not copying the work of other friends. (3) responsible: preparing the necessary group equipment, collecting group observation data, discussing group observation results, and completing individual tasks.

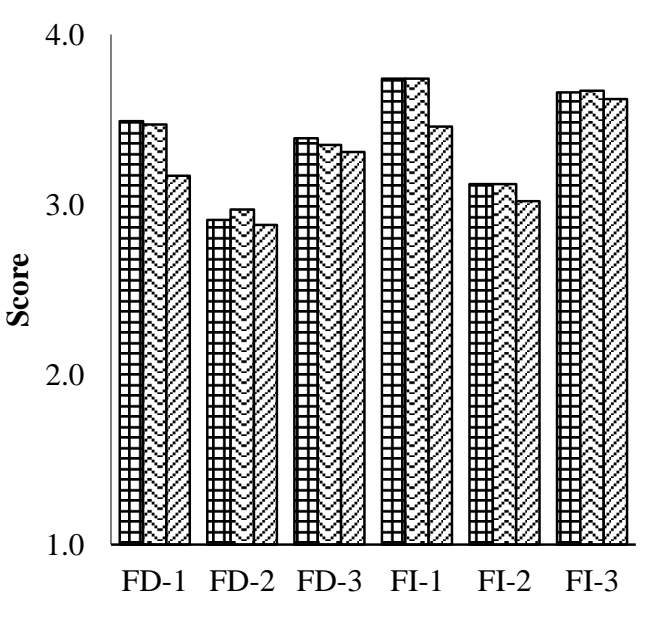

$\boxplus R P P-1 \quad$ QRPP-3 $\square \mathrm{RPP}-6$

Figure 3. Students' character traits of SDN Pasar Lama 1 Banjarmasin; FD-1 = Field Dependence for indicator1, FI-1 = Field Independence for indicator-1. 


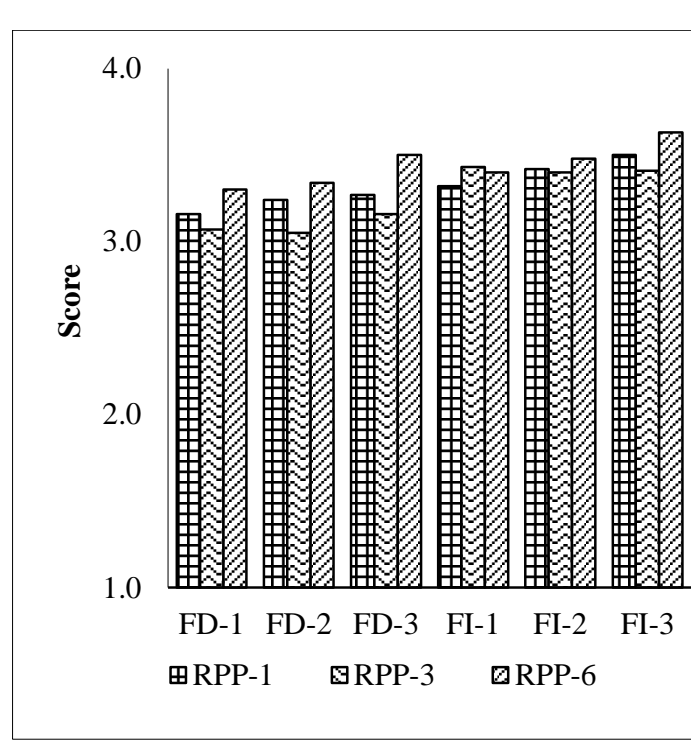

Figure 4. Students' character traits of SDN Pasar Lama 3 Banjarmasin; FD-1 = Field Dependence for indicator-1, FI-1 = Field Independence for indicator1.

\section{DISCUSSION}

Thisstudy implementedcollaboratively the cognitive style-based learning strategy, @UnESaGAIn in the science class of the sixth grade of elementary school. The collaborative learning involves the cooperation of a group of learners to solve a problem, complete a task, or create a product (Laal \& Ghodsi, 2012). The students were grouped into 5-6 heterogeneous members both in terms of gender and in terms of cognitive style. The collaborative classroom management is expected to produce a companion impact of social attitudes and character behaviors. This interaction between students in this collaborative group in many previous studies showed its reliability to improve learning outcomes both on knowledge and attitude aspects (Ali, 2012; Amedu \& Gudi, 2016; Zakaria, Chin \& Daud, 2010). Improving students' skills in collaborative groups according to Hadwin \& Osshige (2011) and Grau \& Whitebread (2012) is the effect of shared regulation that is monitoring and controlling individual performance in groups collectively.It shows a positive relationship between the focus of activity and the type of social regulation. According to Jacobs (2017), although generally learning in a cooperative atmosphere can improve student learning performance, the respect to individual differences is an important part of education.

Based on Fig. 1 and Fig. 2, it can be said that the social skills of students in both schools have the same tendency, where FI students tend to be slightly better than FD students. The average of students' social skills is in good to excellent category. The achievement of social skill scores is almost the same for all indicators which are from good to excellent category. From the overall indicator of social skills observed, only the $2^{\text {nd }}$ indicator, listening to others received the lowest score of 2.00 or in the poorcategory in SDN Pasar Lama 3 Banjarmasin.

In fact, teachers seem to have worked hard to control social interaction along the science class. However, the size of the class or the number of students who are involved in the learning process is quite large with 33 and 39 students. It caused the efforts to manage students' social interaction well is not easy. At this age, children have not fully realized the importance of being socially good. In addition, the size of the class or the number of students in a classroom can influence the effectivity of teacher in managing class well. Some researchers have proven the effect of class size especially on the level of primary and secondary education. The smaller the class size, the easier the classroom management. Therefore, the more time for learning, the more intensive teacher-student interaction, and more personalized teacher attention to each student (Blatchford, Bassett \& Brown, 2011; Blatchford, Russell, Bassett, Brown, \& Martin, 2007). Especially on literacy reading in some European countries, according to Shen \& Konstantopoulos (2017), the class size significantly influences literacy in Russian studentsalthough in some other European countries do not differ significantly based on class size differences.

The social skill of SDN Pasar Baru 3 students seems had developed along the learning process, while in SDN Pasar Lama 1 the students did not show regularity. Nevertheless, the average students' social skills of schoolsreached good category for FI students and FD students. In addition, inculcating attitude requires longer habituation than other aspects such as cognitive and psychomotor. Gautreau and Bins (2012) applied two weeks of inquiry on ecological learning, but resulted in only minor changes in students' attitudes toward the environment and did not differ significantly from the traditional approaches one. Ergül, Şımşeklı, Çaliş, Özdılek, Göçmençelebı, \& Şanli (2011) take 2 semesters to improve attitudes towards science, while Ebrahim (2012) took 54 teaching sessions (@= 45 minutes) of science lesson with cooperative strategy.

In order a collaborative learning will succeed in achieving its goals, teachers should be able to build positive interdependencies among group members, facilitate interaction with promotion, encourage individual accountability, explicitly teach appropriate social skills, and encourage groups to reflect on processes involving in managing tasks and interacting with their peers (Gillies, 2016). According to Roth, Malone, \& Brooks-Gunn (2010) and Durlak, Weissberg, \& Pachan (2010) the higher the participation of students in behavioralsocio-emotional development activities after school, the better their achievement in the developed skills.

Based on the interviews with several students, it was showed a similar trend of answers when asked 
about collaborative activities. For example, when they were asked: "Do you like to study together or learn individually?" almost in both FD students and FI students answered that they like working together because they can exchange opinions with others. This fact differs from the findings of Davis (2004) and Ennis \& Chepyator-Thomson (1990) that adult students with FD cognitive styles tend to have better social attitudes than FI students do. The statement shows that the social development of students at the age of 11-12 years is not optimal so that they have a similar attitude about collaborative learning. In addition, the dependence of students with others in solving the problems is also related to their low learning autonomy.

Fig. 3 and Fig. 4 show that FI group students showed improved behavioral traits compared to FD students. In general, both FD students and FI students have character trait from good to excellent category. Students responded the $2^{\text {nd }}$ indicator lowest among the others. In this indicator, there is a statement "Students write the source if they cite information from others", students have not been able and not yet accustomed to explore and write various sources other than the teaching materials provided. Teaching materials and textbooks belonging to students are used to complete various learning tasks. Information technology utilizing in the form of web or internet as a source of information cannot be done because students do not have access in schools, including the use of handphone facilities. In the era of information, the schools should facilitate the development of information literacy so that students are able to access information widely. According to Hwang, $\mathrm{Wu}$, Zhuang \& Huang (2013) the approach of inquiry learning that allows students to access physical and virtual resources produces conducive learning so that student learning achievement increases and the cognitive load is smaller than the traditional approach. The integration of learning materials with local culture can also contextualize concepts and teach students good cultural values.

The above results support the opinion of Lickona (1991) that character education must be able to learn moral understanding (moral knowing), appreciation of goodness (moral feeling), and also to execute it (behavior), by giving a great benefits to its surroundings. Schools as part of character education should facilitate, encourage and control resources that allow values to be applied sustainably by students. Abu, Mokhtar, Hassan \& Suhan (2015) that the failure of character education in schools is due to the fact that schools have not planned a character education strategy well. In addition, the values developed were not derived from the students or the culture in which the students reside. In order for character enhancement to succeed according to Schumer, Lam, and Laabs (2012) one will learn the character effectively if the characters are applied in social settings through good learning service.
Based on this study, cognitive style-based learning strategy, @UnESa-GAIn is able to produce nurturance effects in the form of social skills and character traits. Students' character traitsimproved over time in both school categories, whereas on social skills there is no consistency of their improvement over time. The development of affective learning results requires relatively longer and more sustained time compared to cognitive and psychomotor learning outcomes. According to Durlak, Weissberg \& Pachan (2010), the successful completion of personal and social skills requires intensive efforts to carry out stage by stage activity in sequence. The students must be actively involved in the learning activity because the exercises in particular play a role as the best way to achieve the skill (active), requires considerable time, and attention to perform tasks relevant to the development of skills (focus), possess specific clear and specific skills development objectives such as self-control skills, problem-solving, cooperation and others (explicit). Conversely, the nurturance effects will also support the success of cognitive-based learning strategy of @UnESa-GAIn on science learning.

\section{CONCLUSION}

The cognitive style-based learning strategy, @UnESa-GAIn, that was applied to science teaching in elementary schools using collaborative settings can provide nurturance effects in the form of social skills and character traits. The students' social skills are well developed throughout learning that includes effective communication, respect for the opinions of others, mutual assistance or collaboration, and contributing ideas unless social skills of listening to others still require improvement. Thecharacter traits are also well developed is a meticulous, responsible character, while honest characters still require improvement. The honest character that needs to be developed here is more related to honesty in writing citations from the sources used that is not accustomed yet to the students. FI students showed a slightly better character development and social skills than FD students although in general both groups have good character traits in good to excellent category.

Many factors that may influence the achievement of social skills and behavior of characters through integration character education include the characteristics of the material, the strategy used, the time, and size of the class. This study and previous research indicate that the learning strategy played an important role as a way to instill students'attitude and character either by design as well as by indirect instruction that provide nurturance effects. Internalization of students' attitudes takes a long time so that the application of learning strategies and observations should be done in a sufficient period and continuously. Class size affected the effectiveness of classroom management, so it can indirectly affect the formation of social skills as well as character traits. These results may serve as a reference for further studies to observe nurturance effects and instructional 
effects such in wider sample usage, difference effects by age, gender, ethnic and even combine with local culture and mobile media.

\section{ACKNOWLEDGMENT}

The authors would like to thank Prof. Budi Jatmiko, Prof. Suhadi Ibnu,andProf. Rudiana Agustini for the suggestions for the betterment of this study. In particular, the gratitude is conveyed to thecosupervisor Prof. Suparman Kardi (rest in peace) whohas given suggestions and has been a good discussion partner alongthis study.

\section{REFERENCES}

[1] Abu, L., Mokhtar, M., Hassan, Z., \& Suhan, S. Z. D. (2015). How to develop character of madrassa students in indonesia. Journal of Education and Learning. Vol. 9(1) pp. 7986.

[2] Ali, I (2012). The effect of cooperative learning strategies on elementary students' science achievement and social skills in Kuwait. International Journal of Science and Mathematics Education, 10,293-314.

[3] Altun, A. \& Cakan, M. (2006). Undergraduate students' academic achievement, field dependent/independent cognitive style and attitude toward computers. Educational Technology and Society, 9(11): 289-297.

[4] Amedu, O. I. \& Gudi, K. C. (2017). Attitude of students towards cooperative learning in some selected secondary schools in nasarawa state. Journal of Education and Practice, 8(10), 29-34.

[5] Ardana, I. M. (2008). Peningkatan kualitas belajar siswa melalui pengembangan pembelajaran matematika berorientasi gaya kognitif dan berwawasan konstruktivis. Jurnal Penelitian dan Pengembangan Pendidikan, 1(1): 1-14.

[6] Armstrong, S. J., Peterson E. R., \& Rayner, S. G. (2012). Understanding and defining cognitive style and learning style: A Delphi study in the context of educational psychology. Education Studies, 38(4), 449455.

[7] Blatchford, P., Bassett, P., \& Brown, P. (2011). Examining the eff ect of class size on classroom engagement and teacher-pupil interaction: Differences in relation to pupil prior attainment and primary vs. secondary schools. Learning and Instruction, 21(6), 715-730.

[8] Blatchford, P., Russell, A., Bassett, P., Brown, P., \& Martin, C. (2007). The eff ect of class size on the teaching of pupils aged 7-11 years. School Effectiveness and School Improvement, 18(2), 147-172.
[9] Cano, J. (1993). Learning style. Dalam E. Norland, J.Heimlich, B. Seevers, K.Smith, \& Johns (Eds.), Understanding and teaching the adult learners. San Francisco: Jossey-Bass Publisher.

[10] Chan, Y. F., Sidhu, G. K., Suthagar, N., Lee, L. F. \& Yap, B. W. (2016). Relationship of inquiry-based instruction on active learning in higher education. Pertanika Journal Social Sciences \& Humanities. 24 (S): 5572.

[11] Cohen, R. J dan Swerdlik, M. E. 2010. Psychological Testing And Assesment: An Introduction to Test and Measurement. $7^{\text {th }}$ edition. New York, NY: MacGraw Hill.

[12] Davis, G, A. (2004). The relationship between learning style and personality type of extention community development program professionals at the Ohio State University. (Disertasi tidak dipublikasikan). Ohio: Ohio State Universiy.

[13] Davis, G, A. (2006). Learning style and personality type preferences of community development extention educators. Journal of Agricultural Education, 47(1): 90-99.

[14] Dick, W, Carey, L, \& Carey, J. O. (2015). The systematic design of instruction. New Jersey: Person.

[15] Dirlikli, M., Aydın, K., Akgün, L. (2016). Cooperative learning in turkey: a content analysis of theses. Educational Sciences: Theory \& Practice, 16(4), 1251-1273.

[16] Durlak, J. A., Weissberg, R. P., Pachan, M. (2010). A meta-analysis of after-school programs that seek to promote personal and social skills in children and adolescents. American Journal of Community Psychology, 45, 294-309. doi: 10.1007/s10464-010-9300-6.

[17]Ebrahim, A. (2012). The effect of cooperative learning strategies on elementary students' science achievement and social skills in Kuwait. International Journal of Science and Mathematics Education, 10, 293-314.

[18]Eliasa, E. I. (2014). Increasing values of teamwork and responsibility of the students through games: integrating education character in lectures. Procedia-Social and Behavioral Sciences, 123, 196-203. doi: 10.1016/j.sbspro.2014.01. 1415.

[19]Ennis, C. D. \&Chepyator-Thomson, J. R. (1990). Learning characteristics of fielddependent children within an analytical concept-based curriculum. Journal of Teaching in Physical Education, 10, 170187.

[20]Ergül, R., Şımşeklı, Y., Çaliş, S., Özdılek, Z., Göçmençelebı, Ş., \& Şanli, M. (2011). 
The effects of inquiry-based science teaching on elementary school students' science process skills and science attitudes. Bulgarian Journal of Science \& Education Policy, 5(1), 48-68.

[21]Fogarty, R. 2009. How to Integrate the Curricula. California, CA: A SAGE Company.

[22] Gautreau, B. T \& Binns, I. C. (2012). Investigating student attitudes and achievements in an environmental placebased inquiry in secondary classrooms. International Journal of Environmental \& Science, 7(2), 167-195.

[23] Gillies, R. M. (2016). Cooperative Learning: Review of Research and Practice. Australian Journal of Teacher Education, 41(3). http://dx.doi.org/10.14221/ajte.2016v41n3.3.

[24] Grau, V. \& Whitebread, D. (2012). Self and social regulation of learning during collaborative activities in the classroom: The interplay of individual and group cognition. Learning and Instruction, 22, 401-412. doi: 10.1016/j.learninstruc.2012.03.003.

[25] Hadi, R. (2015). The integration of character values in the teaching of economics: A Case of selected high schools in Banjarmasin. International Education Studies, 8(7), 11-20.

[26] Hadwin, A.F. \& Oshige, M. (2011). Selfregulation, co-regulation and socially shraed regulation: exploring perspectives of social in self-regulated learning theory. Theachers College Records, 113(2), 240-264.

[27] Hwang, G. J., Wu, P. H., Zhuang, Y. Y., Huang, Y. M. (2013). Eff ects of the inquirybased mobile learning model on the cognitive load and learning achievement of students. Interactive Learning Environments, 21(4), 338-354. $\quad$ http://dx.doi.org/ 10.1080/10494820. 2011.575789

[28] Ibrahim, M. \& Abadi . (2018). Cultivating characters (moral value) through internalization strategy in science classroom, IOP Conf. Series: Materials Science and Engineering $296 \quad$ (2018) 012047. doi:10.1088/1757-899X/296/1/012047.

[29] Isdaryanti, B., Rachman, M., Sukestiyarno, Y. L., Florentinus, T. S., \& Widodo. (2018). Teachers' performance in science learning management integrated with character education. Jurnal Pendidikan IPA Indonesia, 7 (1), 9-15. doi: 10.15294/jpii.v7i1.12887.

[30] Jacobs, G. M. (2017). Introverts and cooperative learning. IASCE Newsletter, 36(1),7-8. Retrieved from http://www.iasce.net/home/newsletters.

[31] Kemendiknas. (2012). Dokumen Kurikulum 2013 [The 2013 Curriculum Document].
Jakarta: Kementerian Pendidikan dan Kebudayaan.

[32] Laal, M. \& Ghodsi, S. M. (2012). Benefits of collaborative learning. Procedia-Social and Behavioral Sciences, 3, 486 - 490. doi:10.1016/j.sbspro.2011.12.091.

[33] Lickona, T (1991). Educating for character: how our school can teach respect and responsibility. New York, NY: Bantam books.

[34] Peraturan Menteri Pendidikan dan Kebudayaan Nomor 21 tahun 2016 tentang Standar Isi Pendidikan Dasar dan Menengah.

[35] Peraturan Menteri Pendidikan dan Kebudayaan Nomor 81A tahun 2013tentang Implementasi Kurikulum.

[36] Peraturan Presiden No. 87 tahun 2017 tentang Penguatan Pendidikan Karakter.

[37] Roth, J. L., Malone, L. M \& Brooks-Gunn, J. (2010). Does the amount of participation in afterschool programs relate to developmental outcomes? A review of the literature. American Journal of Community Psychology, 45, 310-324. doi: 10.1007/s10464-010-9303-3.

[38] Santrock, J. W. (2007). Child development (11th Ed.) (M. Rahmawati \& A. Kuswanti, Trans.). Jakarta, Indonesia: Erlangga.

[39] Sardjijoa \& Hapzi. (2017). Integrating character building into mathematics and science courses in elementary school. International Journal of Environmental \& Science Education, 12(6), 1547-1552.

[40] Shen, T. \& Konstantopoulos, S. (2017). Class size eff ects on reading achievement in Europe: Evidence from PIRLS, Studies in Educational Evoluation, 53, 98-114. http://dx.doi.org/10.1016/j.stueduc.2017.04.0 01.

[41] Sholahuddin, A., Yuanita L. \&Kardi, S. (2013). Menjadikan model PBL sesuai untuk pembelajaran sains di sekolah dasar. Prosieding Seminar Nasional Sains, Prodi Pendidikan Sains PPS Unesa Surabaya, 19 Januari 2013, 706-715.

[42] Sholahuddin, A., Yuanita, L., \& Kardi, S. (2014). @UnESa-GAIn learning strategy for developing the science problem solving ability of elementary school students. Proceeding International Conference on Education Research and Innovation (ICERI), 407-415.

[43] Shumer, R., Lam, C., \& Laabs, B. (2012). Ensuring good character and civic education: Connecting through service earning. Asia Pacific Journal of Education, 32(4): 430440. 
[44] Slavin, R. I. (2009). Education psycology (9th ed.). New Jersey, NJ: Pearson.

[45] Sutarto, H. P., Jaedun, A., \& Nuryadin, E. R. (2017). Dampak pengiring pembelajaran pendekatan saintifik untuk pengembangan sikap spiritual dan sosial siswa. Cakrawala Pendidikan, XXXVI(1), 44-56. doi: 10.21831/cp.v36i1.12792.
[46]Zakaria, E., Chin, L. C. \& Daud, M. Y. (2010). The effects of cooperative learning on students' mathematics achievement and attitude towards mathematics, Journal of Social Sciences , 6 (2): 272-275 